\title{
Unilateral Dynamic Stabilization for Unilateral Lumbar Spinal Pathologies; A New Surgical Concept
}

\author{
Tek Tarafl Lomber Spinal Patolojiler için Tek Tarafl Dinamik \\ Stabilizasyon; Yeni Bir Cerrabi Düşünce
}

\author{
Hakan BOZKUS ${ }^{1}$, Mehdi SASANI ${ }^{1}$, Tunc OKTENOGLU ${ }^{1}$, Ahmet Levent AYDIN ${ }^{2}$, Ali Fahir OZER ${ }^{3}$ \\ ${ }^{1}$ American Hospital, Department of Neurosurgery, Istanbul, Turkey \\ ${ }^{2}$ Istanbul Physical Therapy and Rehabilitation Education and Research Hospital, Department of Neurosurgery, Istanbul, Turkey \\ ${ }^{3}$ Koc University, Faculty of Medicine, Department of Neurosurgery, Istanbul, Turkey
}

Correspondence address: Hakan BOZKUS / E-mail: mhakanb@amerikanhastanesi.org

\begin{abstract}
AIM: Minimally invasive surgical techniques for spine surgery have gained popularity over the last decade. In this study, the authors describe a unilateral dynamic stabilization for unilateral spinal pathologies.

MATERIAL and METHODS: A total of 7 patients with an average age of 46.1 years (range 21-80 years) were included in this study. They are represented various spinal pathologies (degenerative disorders, various tumor pathologies) and having undergone a unilateral facetectomy (or facetectomies) with or without a hemilaminectomy procedure were analyzed in this study. The surgical stabilization was achieved with unilateral dynamic stabilization.

RESULTS: The new surgical concept is described here, and the comparative early results of the Oswestry disability index (ODI) and the visual analog scale (VAS) are presented as well. The preoperative average ODI was 73.14 (range 62-94), and the average VAS was 8.14 (range 7-10). Twelve months after the surgery, ODI was 10.6 (range $0-16)$, and the average VAS was 1 (range $0-2)(p<0.01)$.

CONCLUSION: Although the limited number of cases analyzed reflects data of only early patient outcome, the procedure is safe, feasible, and cost effective. The unilateral dynamic pedicle screw stabilization without fusion is as a technical option to avoid possible segmental instability after unilateral total facetectomy procedure.
\end{abstract}

KEYWORDS: Facet joint, Pedicle screw, Lumbar stabilization

Öz

AMAÇ: Omurga cerrahisinde az invaziv cerrahi teknikler geçen on yıl boyunca popülerlik kazanmıştır. Bu çalışmada, yazarlar tek taraflı omurga patolojileri için tek taraflı dinamik stabilizasyonu tanımlamaktadır.

YÖNTEM ve GEREÇLER: Ortalama yaşları 46,1 (21-80 arası) olan toplam 7 hasta çalışmaya alınmıştır. Değişik omurga patolojileri (dejeneratif hastalıklar, çeşitli tumor patolojileri) olan hastalara tek taraflı fasetektomi (veya fasetektomiler) ve/veya hemilaminektomi girişimi yapılmıştır. Cerrahi stabilizasyon tek taraflı dinamik stabilizasyon ile uygulanmıştır.

BULGULAR: Yeni bir cerrahi görüş tanımlanarak, karşılaştırmalı olarak Oswestry fonksiyon endeksi (ODI) ve ağrı skoru (VAS) sunulmaktadır. Cerrahi öncesi ODI 73,14 (62-94 aralığında) ve VAS 8,14 (7-10 aralığında) dır. Cerrahi sonrasında 1. yılda; ODI 10,6 (0-16 arası) ve VAS 1 (0-2 arası) $\operatorname{dir}(\mathrm{p}<0.01)$.

SONUÇ: Kısıtlı sayıdaki hastalar ile erken sonuçların irdelenmesine rağmen, bu girişim; güvenli, uygulanabilir ve maliyet açısından uygundur. Füzyonsuz tek tarafı dinamik pedikül vida stabilizasyonu, tek taraflı fasetektomi sonrası olası gelişebilecek segmental stabilizasyon bozulmasını önlemek açısından teknik bir alternatifdir.

ANAHTAR SÖZCÜKLER: Faset eklemi, Pedikül vidası, Lomber stabilizasyon

\section{INTRODUCTION}

Unilateral lumbar spinal pathologies, such as the foraminal or extraforaminal disc herniations, spinal stenosis related to facet hypertrophy, and spinal cord tumors (e.g., neurinoma, menengioma), can be treated using a unilateral spinal approach. In these cases, removing one side of the total facet articulation(s), with or without performing a laminectomy, may allow access to the pathology.
Facet joints are diarthroidal synovial joints with cartilage surfaces that provide a low-friction interface to facilitate the limited translation and rotation during the normal range of motion in the functional spinal unit (FSU). The bony parts of the facet support the compressive loads, whereas the facet capsular ligament resists tensile forces that develop across the joint during any normal motion. The facet joint carries an estimated $16-25 \%$ of the compressive load $(2,17)$.In addition to transmitting the compressive load, the facet joints 
also provide torsional stiffness and resistance to shear and translational forces $(12,16)$. According to the biomechanical perspective, the one-sided total lumbar facetectomy produces a significant increase in the range of motion (ROM) in flexion and in axial rotation to the opposite side. Hence, a total facetectomy, even when performed unilaterally while preserving the posterior ligaments, may create instability in the lumbar motion segment or FSU $(1,4)$. A considerable increase in the angular motion was also observed in the finite element analysis when the facet joint was removed, indicating that the facet joint restricts the torsion movement $(11,19)$.

Because of the role of facet articulation, some authors prefer the more stable facet-sparing laminectomy procedure over the combined bilateral facetectomy and laminectomy procedure when spinal canal decompression is needed for the multilevel lumbar spinal segment (5).

The unilateral spinal pedicle screw with fusion has been reported as an option for the treatment of some degenerative processes of the lumbar spine with favorable results $(6,9)$. However, the application of unilateral dynamic stabilization has not yet been reported in the literature.

In this study, unilateral dynamic pedicle screw stabilization without fusion is presented as a technical option to avoid possible segmental instability after unilateral facetectomy with or without the laminectomy procedure.

The authors hypothesize that using the dynamic pedicle screws with either rigid or dynamic rod combinations may create adequate stability after unilateral facetectomy. This technique may also reduce adjacent segment degeneration and the complications associated with rigid stabilization techniques.

\section{MATERIAL and METHODS}

The authors performed 7 unilateral total facetectomy procedures with or without laminectomies in the lower thoracic and in the lumbar spine for various pathologies, including disc herniation, facet osteoarthritis, trauma, and tumor.

Four male and three female patients with an average age of 46.1 years (range 21-80 years) were included in this study. There were three cases of foraminal or extraforaminal disc herniations. The remaining cases had one of the following pathologies: a lateral recess stenosis due to facet hypertrophy, a pedicle tumor, an extradural spinal cord tumor, or an extra/ intradural spinal cord tumor. A unilateral one-level total facetectomy was performed in six cases, and a unilateral two-level total facetectomy was performed in the case of the pedicle tumor.

All pedicle screws were hinged-design dynamic pedicle screws (Cosmic (Ulrich, Ulm, Germany) or Safinaz screws, (Medikon AS, Turkey)). The dynamic rod stabilization (Dream Dynamic System, Globalmedics, Auckland, New Zealand) with a dynamic pedicle screw was used as a hybrid model in three cases. The remaining cases were performed using single level stabilization with a rigid rod. The screws were 5.5 or $6.5 \mathrm{~mm}$ in diameter and 45,50 , or $55 \mathrm{~mm}$ in length. The rods were 5 or $5.5 \mathrm{~mm}$ in diameter.

The procedures were performed at various levels of the spine as follows: L3-4 (two cases), L4-5 (one case), L5-S1 (one case), T9-T11 (one case), and T12-L1 (two cases). The left-sided and the right-sided approaches were performed in four and three cases, respectively. The surgical and demographic data of the cases are summarized in Table I.

The quality of life and pain scores of the cases were evaluated with the Oswestry Disability Index (ODI) and the Visual Analog Scale (VAS) preoperatively and at 12 months following the surgery. The operative time, blood loss, and duration of hospital stay were recorded.

All patients underwent preoperative anteroposterior and lateral upright $\mathrm{x}$-rays, magnetic resonance imaging (MRI), and/or computed tomography (CT) examination of the thoracolumbar spine. During the postoperative period, all cases had anteroposterior and lateral upright x-rays of the thoracolumbar spine before discharge from the hospital and at 12 months. All but two of the patients had an MRI or CT examination postoperatively because of their preoperative tumor diagnoses.

\section{CASE ILLUSTRATIONS}

Case no. 2: The patient is a 33 years old male with a left-sided L4-5 foraminal/extraforaminal disc herniation (Figure $1 \mathrm{~A}$, B). The performed surgical procedure was a unilateral leftsided L4-5 total facetectomy and sequestrectomy. Segmental stabilization at L4-5 was achieved using a unilateral dynamic pedicle screw with a rigid rod on the left side (Figure 1C, D).

Case no. 6: The patient is a 21 years old male with an extradural tumor at the level of L3 (Figure 2 A, B). The performed surgical procedure was a unilateral right-sided L3-4 total facetectomy and an L3 hemilaminectomy for tumor removal. The segmental stabilization at L3-4 was achieved with a unilateral hybrid model. The pathological diagnosis was chondroblastoma (Figure 2 C, D). During his routine follow up at 12 months, a broken dynamic rod was observed in his lateral upright lumbosacral and dynamic x-rays, and the flaw was characterized as a hardware failure (Figure 3A-D). Even though the patient had no complaints at that time, the surgical replacement of the rod was recommended. However, the patient refused to have the procedure performed. He went on to complete the 30-month follow-up without any further setbacks.

\section{Surgical Technique}

After induction with general anesthesia, the patient was placed in the prone position on a radiolucent table. A preoperative radiograph was obtained to localize the targeted level for the procedure. To begin the operation, the surgeon made a midline skin incision and created a unilateral fascial opening at the appropriate level. The unilateral paravertebral muscle dissection was completed by conventional means 
Table I: Summary of the Patients' Demographic Data

\begin{tabular}{|c|c|c|c|c|}
\hline Case No & Age/Sex & Pathology & Surgical Procedure & Stabilization (unilateral) \\
\hline 1 & $44 / M$ & $\begin{array}{l}\text { L3-4 foraminal disc } \\
\text { herniation }\end{array}$ & Left L3-4 facetectomy + sequestrectomy & $\begin{array}{l}\text { Left L3-4 dynamic pedicle } \\
\text { screw+ rigid rod }\end{array}$ \\
\hline 2 & 33/M & $\begin{array}{l}\text { L4-5 foraminal/ } \\
\text { extraforaminal disc } \\
\text { herniation }\end{array}$ & Left L4-5 facetectomy + sequestrectomy & $\begin{array}{l}\text { Left L4-5 dynamic pedicle } \\
\text { screw+ rigid rod }\end{array}$ \\
\hline 3 & $31 / F$ & $\begin{array}{l}\text { T10 pedicle osteoid } \\
\text { osteoma }\end{array}$ & Right T10 facetectomy+ tumor resection & $\begin{array}{l}\text { Right T9-10-11 dynamic } \\
\text { pedicle screw+ dynamic rod }\end{array}$ \\
\hline 4 & $80 / F$ & $\begin{array}{l}\text { L1 fracture, T12-L1 } \\
\text { disc herniation }\end{array}$ & $\begin{array}{l}\text { Right T12-L1 facetectomy+ T12 } \\
\text { hemilaminectomy+ T12-L1 microdiscectomy + } \\
\text { L1 bilateral kyphoplasty }\end{array}$ & $\begin{array}{l}\text { Right T12-L1 dynamic } \\
\text { pedicle screw+ rigid rod }\end{array}$ \\
\hline 5 & $54 / F$ & T12 level neurinoma & $\begin{array}{l}\mathrm{T} 12-\mathrm{L} 1 \text { facetectomy+ Left } \mathrm{T} 12 \\
\text { hemilaminectomy+ tumor resection }\end{array}$ & $\begin{array}{l}\text { Left T12-L1 dynamic pedicle } \\
\text { screw+ dynamic rod }\end{array}$ \\
\hline 6 & $21 / \mathrm{M}$ & $\begin{array}{l}\text { L3-4 } \\
\text { chondroblastoma }\end{array}$ & $\begin{array}{l}\text { Right L3-4 facetectomy+ L3 hemilaminectomy+ } \\
\text { tumor resection }\end{array}$ & $\begin{array}{l}\text { Right L3-4 dynamic pedicle } \\
\text { screw+ dynamic rod }\end{array}$ \\
\hline 7 & $60 / \mathrm{M}$ & $\begin{array}{l}\text { L5-S1 facet } \\
\text { hypertrophy }\end{array}$ & Left L5-S1 facetectomy & $\begin{array}{l}\text { Left L5-S1 dynamic pedicle } \\
\text { screw+ rigid rod }\end{array}$ \\
\hline
\end{tabular}

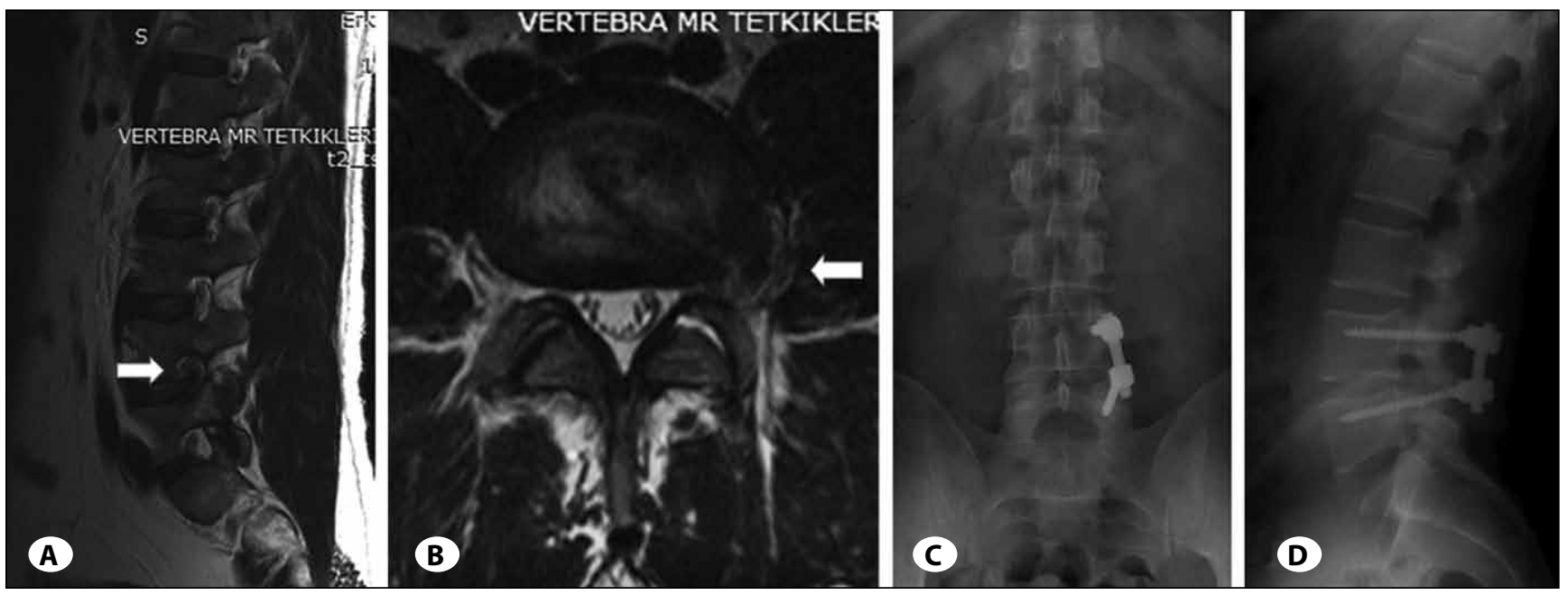

Figure 1: Magnetic resonance imaging (MRI) of the left-sided L4-5 foraminal/extraforaminal disc herniation for case no. 2 (A: Sagittal plain view, B: Axial plain view). C, D: The postoperative lumbosacral x-ray after dynamic pedicle screw-rigid rod stabilization of L4-5 level at 12-month follow-up. The white arrows indicate the herniated disc fragment.

using the monopolar electrocautery. The unilateral facet articulation and lamina were removed by a high-speed bur. After removing the pathologic malformation (disc herniation, tumor, etc.), the unilateral dynamic pedicle screws were placed under fluoroscopic visualization.

The dynamic rod and the dynamic pedicle screw combination were referred to as the hybrid model in this study and was applied in three cases. The patients involved in these three cases were preoperatively diagnosed with extra-medullar tumors, and the pathologies in two of the three patients were localized to the low thoracic level (T10 and T12). In the remaining case, the tumor was localized at the level of L3. No bone fusion material was used during the surgery.
After implantation, the fascia and the skin were closed in the standard fashion.

\section{Statistical Analysis}

Clinical parameters (ODI and VAS) were statistically compared between preoperative and postoperative data with the paired t-test.

\section{RESULTS}

The operative time lasted an average of 142.5 minutes (a minimum of 90 minutes and a maximum of 210 minutes). The patients stayed in the hospital an average of 3.5 days (a minimum of 2 days and a maximum of 5 days). There was no 


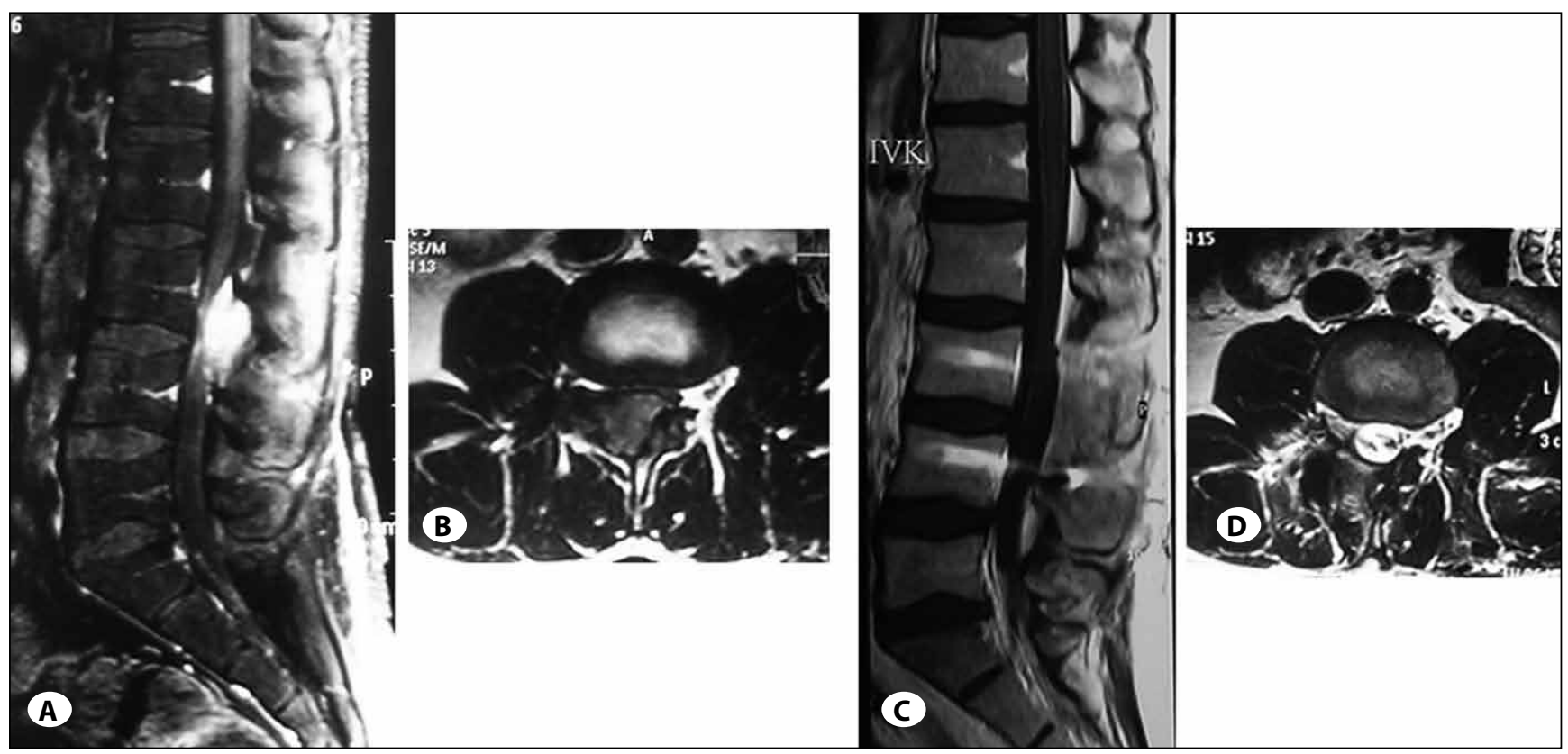

Figure 2: Contrast enhanced magnetic resonance imaging (MRI) of a chondroblastoma at the level of L3 for case no. 6 (A: Preoperative sagittal plain view, B: Preoperative axial plain view, C: Postoperative sagittal plain view, D: Postoperative axial plain view).

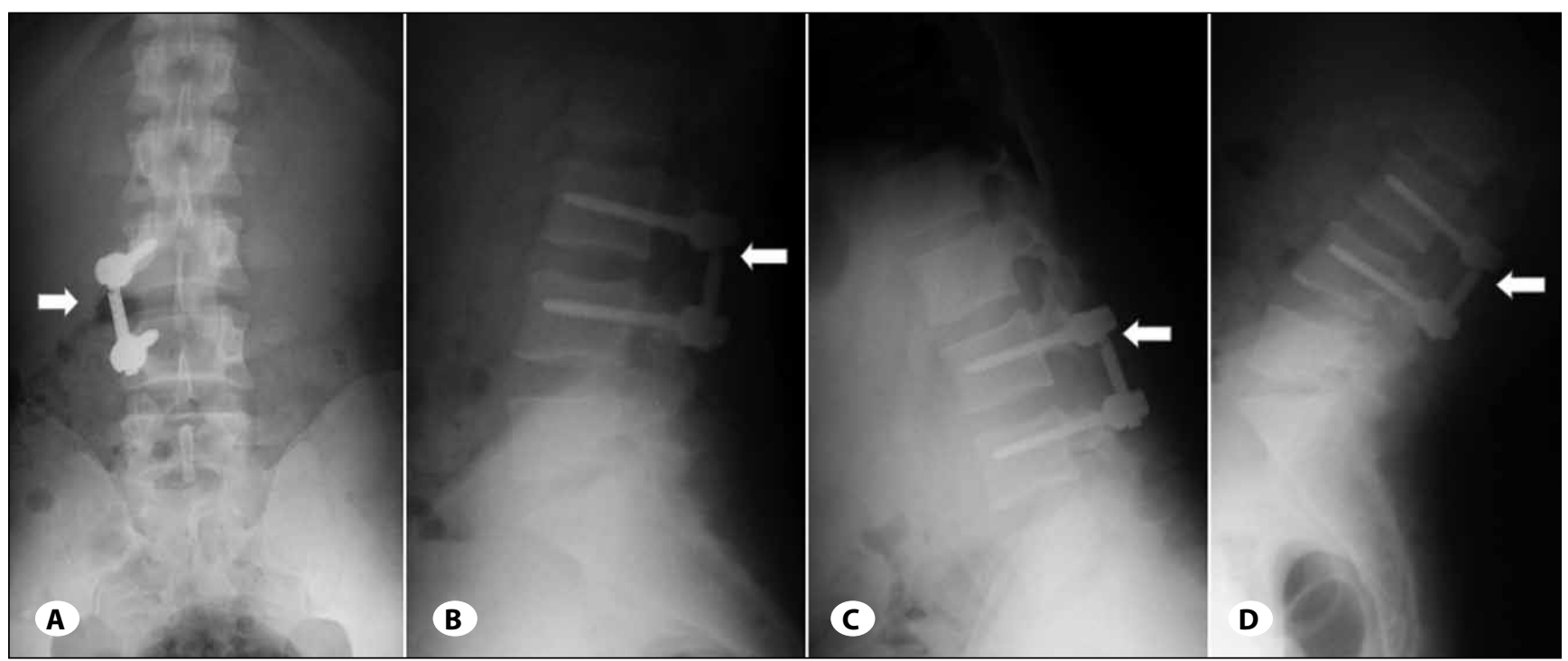

Figure 3: Postoperative lumbosacral x-ray at 12-month follow-up. Coronal plan (A) and sagittal plain views (B: Neutral, C: Hyperflexion, D: Hyperextention) for case no. 6. The white arrows indicate broken side of the dynamic rod.

significant blood loss recorded during the procedures, and there was no need for blood transfusion during hospitalization.

The preoperative average ODI was 73.14 (range 62-94), and the average VAS was 8.14 (range 7-10). The postoperative ODI was 10.6 (range 0-16), and the average VAS was 1 (range $0-2$ ). Twelve months after the surgery, the average ODI and VAS assessments decreased significantly compared to the preoperative scores. $(p<0.01$, Table II)

There were two postoperative complications. The patient with an extra/intradural neurinoma (case no. 5) developed a wound collection after the procedure, which required surgical drainage of the collection before being discharged from the hospital. There were no infectious agents isolated in the antibiogram test, and the patient recovered without any additional problems. The second postoperative complication (case no. 6) was presented previously in the case illustration section.

\section{DISCUSSION}

The authors of the present study hypothesize that the resection of one side of the total facet articulation causes an unstable condition and requires a fortifying procedure unless surrounded by osteophytic spurs that would provide a 
Table II: Patients' Outcome ODI (Oswestry Disability Index) and VAS (Visual Analogue Scale)

\begin{tabular}{|c|c|c|c|c|}
\hline & \multicolumn{3}{|c|}{ Preoperative } & \multicolumn{2}{c|}{ Postoperative (12 nd month) } \\
\hline Case No & ODI & VAS & ODI & 0 \\
\hline $\mathbf{1}$ & 74 & 8 & 6 & 0 \\
\hline $\mathbf{2}$ & 94 & 10 & 8 & 1 \\
\hline $\mathbf{3}$ & 70 & 8 & 12 & 2 \\
\hline $\mathbf{5}$ & 62 & 7 & 16 & 2 \\
\hline $\mathbf{6}$ & 64 & 8 & 10 & 2 \\
\hline
\end{tabular}

stabilizing effect. In contrast to solid stabilization techniques, the non-fusion systems maintain intersegmental motions and reduce adjacent segment degeneration and the complications associated with bone fusion $(3,13,14)$.

In the present study, all cases underwent a unilateral facetectomy (or facetectomies) with or without a hemilaminectomy (or hemilaminectomies) for unilateral spinal pathology. The soft tissues, intervertebral disc tissues, and interspinous and supraspinous ligaments of the contralateral side remained intact. The advantages of the unilateral pedicle stabilization are as follows: the onesided paravertebral muscle dissection is sufficient for this procedure; there is no risk for post-surgical late atrophy of the contralateral paravertebral muscle; the operative time and the duration of the hospital stay are reduced; the procedure is more cost effective than the bilateral stabilization alternative; and, by eliminating the need for the contralateral pedicle screw implantation, the risk for complications is reduced.

A limited number of lumbar facet replacement systems have been mentioned in the literature. At this moment, there is no preferred technique $(8,15,20)$. The stabilization method in this study was chosen to achieve "adequate stabilization but not overt stabilization" after a unilateral facetectomy (or facetectomies) using a minimally invasive surgical approach. The described stabilization herein may act as unilateral facet replacement system in patients with unilateral facetectomy (or facetectomies) performed.

The clinical results of both unilateral and bilateral pedicle screw stabilization with fusion have been documented in the literature. However, there is no significant difference between the benefits gained by patients after either procedure. Unilateral pedicle screw stabilization with bone fusion is a treatment option for lumbar spondylosis and spondylolisthesis $(6,9,10)$. Although there is no data available that compares the unilateral facetectomy (facetectomies) with bilateral dynamic pedicle screw stabilization or unilateral dynamic pedicle screw, the results of the ODI and VAS scores at the early follow up of the present study suggest that the unilateral dynamic stabilization after a unilateral facetectomy (facetectomies) is the treatment of choice. However, the small number of patients is making it difficult to make a statistical evaluation.
Biomechanical studies on unilateral rigid pedicle screw stabilization have reported that this type of stabilization has less rigidity than bilateral rigid pedicle screw stabilization $(7,18)$. However, these studies do not account for the effect on the paravertebral muscles.

The hardware failure (14\%) present in this study may not reflect the actual rate of this type of postsurgical complication due to the limited number of patients analyzed. This failure can be explained by the mechanical behavior of simple beam bending test. Normally, both rigid and dynamic rods are composed of homogeneous material, and the force imposed at one end is translated as an equal and opposite force at the other end of the rod. Moreover, the fixed relationship between stress and strain for the beam material is the same for both tension and compression. ( $\sigma=E . e),[(\sigma$; stress), $(E$; Young's Modulus, Elastic Modulus), (e; Strain)]. Because of the lower E value associated with the dynamic rod, this rod may be prone to failure when used unilaterally.

The failed hardware was a hybrid model applied at the level of L3-4, where the segmental motion may be caused by the additional multidirectional stress imposed on the dynamic rod. The other hybrid models were located at less mobile segments of the spine (one was located at T12-L1 and the other was located at T9-11), and no hardware failures occurred at these sites. Further biomechanical and clinical investigations are needed in order to determine the proper localization for the use of the unilateral hybrid model stabilization.

The small number of cases included and the short follow-up duration limit the analysis presented here. Further radiological study is needed to evaluate the contralateral facet articulation for long-term follow up.

\section{CONCLUSION}

The present study suggests that if unilateral facetectomy (or facetectomies) is used for the treatment of unilateral spinal pathologies, the stabilization can be achieved with a unilateral dynamic pedicle screw and a rigid or dynamic rod. The advantages include reduction in operative time, a more cost effective approach, and the adequate stabilization of the involved FSU. 


\section{REFERENCES}

1. Abumi K, Panjabi MM, Kramer KM, Duranceau J, Oxland T, Crisco JJ: Biomechanical evaluation of lumbar spinal stability after graded facetectomies. Spine 15(11): 1142-1147, 1990

2. Adams MA, Hutton WC: The effect of posture on the role of the apophysial joints in resisting intervertebral compressive forces. J Bone J Surg (Br) 62(30): 358-362, 1980

3. Bozkus H, Senoglu M, Baek S, Sawa AGU, Ozer F, Sonntag VKH, Crawford N: Dynamic lumbar pedicle screw-rod stabilization: In vitro biomechanical comparison with standard rigid pedicle screw-rod stabilization. J Neurosurg Spine 12: 183-189, 2010

4. Cusick JF, Yoganandan N, Pintar FA, Reinartz JM: Biomechanics of sequential posterior lumbar surgical alterations. J Neurosurg 76(5): 805-811, 1992

5. Detwiler PW, Spetzler CB, Taylor SB, Crawford NR, Porter RW, Sonntag VKH: Biomechanical comparison of facet-sparing laminectomy and Christmas tree laminectomy. J Neurosurg (Spine) 99: 214-220, 2003

6. Fernandez-Fairen $M$, Sala $P$, Ramirez $H$, Gil J: A prospective randomized study of unilateral versus bilateral instrumented posterolateral lumbar fusion in degenerative spondylolisthesis. Spine 32(4): 395-401, 2007

7. Goel VK, Lim TH, Gwon J, Chen JY, Winterbottom JM, Park JB, Weinstein JN, Ahn JY: Effects of rigidity of an internal fixation device. A comprehensive biomechanical investigation. Spine 16(3): 155-161,1991

8. Goel VK, Mehta A, Jangra J, Faizan A, Kiapour A, Hoy RW, Fauth AR: Anatomic facet replacement system (AFRS) restoration of lumbar segment mechanics to intact: A finite element study and in vitro cadaver investigation. SAS Journal 1(1): 46-54, 2007

9. Kabins MB, Weinstein JN, Spratt KF, Found EM, Goel VK, Woody J, Sayre HA: Isolated L4-L5 fusion using the variable screw placement system: Unilateral versus bilateral. J Spinal Disord 5(1): 39-49, 1992
10. Kim JG, Jin YJ, Chung SK, Kim KJ, Kim HJ: Unilateral augmented pedicle screw fixation for foraminal stenosis. J Korean Neurosurg Soc 46: 5-10, 2009

11. Lee KK, Teo EC: Effects of laminectomy and facetectomy on the stability of the lumbar motion segment. Medical Engineering\&Physics 26: 183-192, 2004

12. Lu WW, Luk KD, Holmes AD, Cheung KM, Leong JC: Pure shear properties of lumbar spinal joints and the effect of tissue sectioning on load sharing. Spine 30: E204-E209, 2005

13. Oktenoglu T, Ozer AF, Sasani M, Kaner T, Canbulat N, Ercelen O, Sarıoglu AC: Posterior dynamic stabilization in the treatment of lumbar degenerative disc disease: 2 year follow-up. Min Invasive Neurosurg 53(3): 112-116, 2010

14. Ozer AF, Crawford NR, Sasani M, Oktenoglu T, Bozkus H, Kaner T, Aydin S: Dynamic lumbar pedicle screw-rod stabilization: Two-year follow-up and comparison with fusion. Open Orthop J 4(4): 137-141, 2010

15. Shaw MN: A biomechanical evaluation of lumbar facet replacement systems. (MS thesis), University of Toledo, 2005

16. White AA III, Panjabi MM: Clinical biomechanics of the spine. $2^{\text {nd }}$ ed. Philadelphia: JB Lippincott, 1990:318-321

17. Yang KH, King Al: Mechanism of facet load transmission as a hypothesis for low back pain. Spine 9(6): 557-565, 1984

18. Yucesoy K, Yuksel KZ, Baek S, Sonntag VK, Crawford NR: Biomechanics of unilateral compared with bilateral lumbar pedicle screw fixation for stabilization of unilateral vertebral disease. J Neurosurg Spine 8: 44-51, 2008

19. Zander T, Rohlman A, Klöckner C, Bergmann G: Influence of graded faxetectomy and laminectomy on spinal biomechanics. Eur Spine J 12: 427-434, 2003

20. Zhu Q, Larson CR, Sjovold SG, Rosler DM, Keynan O, Wilson DR, Cripton P, Oxland TR: Biomechanical evaluation of the total facet arthroplasty system. Spine 32 (1): 55-62, 2007 